\title{
PIONEER LICHEN COMMUNITIES OF THE TETERIV RIVER BASIN (UKRAINE)
}

\author{
N. V. KAPETS ${ }^{1}$, O. O. BARsuKov ${ }^{1}$, D. S. VynOKURov ${ }^{1}$ and I. V. KHOMYAK ${ }^{2}$ \\ ${ }^{1}$ M. H. Kholodny Institute of Botany, 2 Tereshchenkivska Str., Kyiv, 01004 Ukraine \\ E-mails: kapets_n@ukr.net,narak-zempo@yandex.ru \\ ${ }^{2} I v a n$ Franko Zhytomyr State University, 40 Velyka Berdychivska Str., Zhytomyr \\ 10008, Ukraine; E-mail: ecosystem_lab@ukr.net
}

(Received 23 March, 2018; Accepted 10 August, 2018)

The results of phytosociological studies of pioneer lichen communities of siliceous outcrops carried out in 2014-2016 in Teteriv River basin (Ukraine) are provided. The dataset of 302 relevés was analysed, 6 associations and 1 subassociation from 3 classes were distinguished as a result of the phytosociological survey in the Teteriv River basin. Four associations, i.e.: Aspicilietum contortae Kaiser ex Klement 1955, Cladonietum mitis Krieger 1937, Parmelietum conspersae Hilitzer 1925, Parmelietum somloensis Wirth 1995 and the alliance Aspicilion calcareae Albertson ex Roux 1978 are new for Ukraine, and one new association Aspicilio cinerei-Ramalinetum pollinariae Kapets et Khomyak, ass. nova is described here.

Key words: Aspicilietum cinereae, Aspicilio cinerei-Ramalinetum pollinariae, Aspicilietum contortae, Cladonietum mitis, cryptogam communities, siliceous outcrops, syntaxonomy, Parmelietum conspersae, Parmelietum somloensis

\section{INTRODUCTION}

Lichens like the other cryptogams differ from vascular plants in many characteristics (poikilohydry, intensity of biochemical processes, rootless structure, etc.). Due to specific biological processes lichens can colonise extreme habitats that would be unsuitable for most vascular plants, thus forming a special type of vegetation. Cryptogamic communities can form special vegetation types and these can be classified as separate syntaxa. The study of lichen communities is one of the sources of additional information on habitats and monitoring changes therein (Bültman and Daniëls 2009, Paus 1997). It is extremely important to study habitats and biotopes with poor vascular plant vegetation (siliceous screes and rocky slopes, 8150 (Medio-European upland siliceous screes), 8220 (siliceous rocky slopes with chasmophytic vegetation), 8230 (siliceous rock with pioneer vegetation of the Sedo-Scleranthion Br.-Bl. et Richard 1950 or of the Sedo albi-Veronicion dilleni Korneck 1974) according to the Directive 1992/43/EEC, etc.). Some types of these habitats are located in the Teteriv River basin. It should be noted that lichen communities of these habitats, unlike vascular plant vegetation, has never been studied in Ukraine. 
The low degree of recovery is one of the features inherent to extreme rock habitats, which increases importance of studying changes therein. Some more detailed study covering all components of these habitats can help improving protection at the study area.

Lichen communities of Ukraine have hitherto been researched poorly. Some information to this end was published first in the early 20th century. The data on three epilithic lichen communities from central and northern Ukraine was published in 1927 by Oxner (1927). The author used an original method to find out the percentage cover of each species. The studies of epilithic, epiphytic and epigeic lichen communities of central Ukraine using Braun-Blanquet method were carried out in the first half of the 20th century. These data are also included in 'Prodromus der mitteleuropäischen Flechtengesellschaften' (Klement 1955). Some peculiar vegetation studies on cryptogamic communities have been carried out in various parts of Ukraine (Crimea Peninsula, steppe zone and forest-steppe zone) at the beginning of the 21st century (Gapon 2013, Khodosovtsev 2015, Khodosovtsev et al. 2011, 2014, Redchenko 2004).

The objective of this research was to investigate the syntaxonomic structure of the pioneer lichen communities of siliceous outcrops in the Teteriv River basin (Ukraine). This information will not merely provide intimate knowledge covering syntaxonomy of the pioneer vegetation on the siliceous screes and rocky slopes, but it will also be interesting for further syntaxonomic research of the lichen communities of Ukraine. More detailed study covering this type of habitats will facilitate development of an efficient conservation system to be applied at this territory.

\section{MATERIAL AND METHODS}

\section{Study area}

Geographic position. The Teteriv River flows in the north of Ukraine and flows into the Dnieper River. The total length of the river is $365 \mathrm{~km}$, the average velocity ranging from $0.3-0.5 \mathrm{~m} / \mathrm{s}$ to $1.0-2.5 \mathrm{~m} / \mathrm{s}$ at rock ledges. The Teteriv River basin is located in the northwestern part of the Ukrainian Crystal Shield, covering the area of $15,100 \mathrm{~km}^{2}$. The Hnylopiat, Huyva, Irsha and Zdvyzh Rivers are the major tributaries of the Teteriv River. The rivers' banks in the basin are normally steep, 1-2 $\mathrm{m}$ high, often with outcrops forming riverside rocks. The major type of the area landscape is outwash plains resting on crystalline basement. The major types of soils are turf-podzolic, turf-podzol, black and forest soils. The outcrops form rock ledges, riverside rocks, and sometimes even canyons of 25 to $30 \mathrm{~m}$ wide (Fig. 1). The crystalline rocks are represented by granitoids of the Kirovohrad-Zhytomyr and the Korosten intru- 
sive sheets. Most of the exposures are located at the upper and middle course of the Teteriv River basin. Therefore, these sections are the most suitable for studying epilithic lichen communities (Marinich 1963, Marinich et al. 1985).

Vegetation and climate. Some portions of the Teteriv River basin's upper course are located at the forest-steppe zone of Ukraine. The middle and lower course of the basin are located at the forest zone. More than half of the area is covered with forest vegetation, as represented by three major types: acidophilous beech and mixed fir-beech forests (ass. Ficario vernae-Ulmetum campestris Knapp ex Medwecka-Kornaś, Tilio cordatae-Carpinetum betuli Traczyk 1962, Poo nemoralis-Tilietum cordatae Firbas et Sigmond 1928, Potentillo albaeQuercetum Libb. 1933); acidophilous oak and oak-birch forests on nutrientpoor soils (ass. Trientalo europaeae-Quercetum roboris Vorobyov 2014) and pine forests on nutrient-poor and hydromorphic soils (ass. Dicrano-Pinetum Preising et Knapp ex Oberd. 1957, Molinio-Pinetum Matuszkiewicz (1973) 1981, Peucedano-Pinetum Mat. (1962) 1973, Vaccinio uliginosi-Pinetum de Kleist 1929). Mesotrophic regularly flooded alder (ass. Ribo nigri-Alnetum SolińskaGórnicka 1975, Sphagno squarrosi-Alnetum Sol.-Gorn. (1975) 1987) and willow carrs (ass. Salicetum pentandro-cinereae Pass. 1961) are frequent in floodplains (Didukh et al. 2011, Orlov and Yakushenko 2005).

The geomorphological features of this area facilitated forming special types of vegetation. The chasmophytic vegetation of crevices, rocky ledges and faces of rocky cliffs (ass. Hypno-Polypodietum Jurko et Peciar 1963, Asplenio-Cystopteridetum fragilis Oberd. (1936) 1949, etc.) and pioneer vegetation on shallow soils on rocky siliceous rocks (ass. Melico transsylvanicae-Sedetum ruprechtii Kontar 1998, Thymo pulegioidis-Sedetum sexangularis Didukh et Kontar 1998 (Didukh et al. 2011) are some of them.

The climate of the Teteriv River basin is temperate continental, with increasing continentality from the northwest to the southeast. The average annual temperature is $+6{ }^{\circ} \mathrm{C}$ to $+7{ }^{\circ} \mathrm{C}$. The average temperature is $+19.4{ }^{\circ} \mathrm{C}$ in July, and $-5.7^{\circ} \mathrm{C}$ in January. The average annual amount of precipitation reaches about $562 \mathrm{~mm}$.

\section{Research methods}

A total of 302 phytosociological relevés had been collected in 2014-2016. The vast majority of relevés were done on lichen-rich outcrops, and a few relevés on sandy areas near the outcrops. The phytosociological relevé sampling procedure followed the Braun-Blanquet approach (Braun-Blanquet 1964, Mirkin and Rozenberg 1983). Some guidelines on selecting relevés plots of epilithic lichen communities, as proposed by Klement (1955), were also considered. The relevés include lichens, bryophytes and some epilithic fungi of the genus 
Lichenothelia D. Hawksw. The lichens and bryophytes were identified according to the standard techniques and using light microscopy (Kondratyuk and Martynenko 2006). The analysis of some ecological characteristics (pH of the substratum, light, xerophytism) was completed relying on scales proposed by Nimis and Martellos (2008), and by Wirth (2010).

The relevés were stored in the Turboveg 2.0 database (Hennekens 2009). The analysis of lichen communities was completed with the Juice 7.0 software package (Tichý 2002) using Two-way indicator species analysis (Twinspan) (Hill 1979) with the following default parameters: 3 pseudospecies cut levels: $0 \%, 5 \%, 25 \%$; minimum group size -5 ; maximum level of division -6 . The phi fidelity index was used to identify diagnostic species (Chytrý et al. 2002). We considered diagnostic species with phi $>25 \%$, constant species with frequencies $>25 \%$, dominant species with a mean cover of more than $10 \%$ and minimum frequency $10 \%$. The names of syntaxa were specified according to the third edition of the International Code of Phytosociological Nomenclature (Weber et al. 2000). The names of the high level syntaxa were disclosed according to the modern European hierarchical system of classification of vascular plants, bryophytes, lichens and algae (Mucina et al. 2016). Species names are given according to the 'Index Fungorum' for lichens (CABI 2018), and according to Boiko $(2008,2014)$ for bryophytes.

\section{RESULTS}

The pioneer communities of the study area are represented by six associations, one subassociation of three alliances and three classes. As a result of the syntaxonomic interpretation of phytosociological data, the following chart of the pioneer lichen communities of the Teteriv River basin was created.

Cl. Rhizocarpetea geographici Wirth 1972

Ord. Rhizocarpetalia Klement 1949

All. Parmelion conspersae Hadac in Klika et Hadac 1944

Aspicilietum cinereae Frey 1922

Parmelietum conspersae Hilitzer 1925

Parmelietum somloensis Wirth 1995

Aspicilio cinerei-Ramalinetum pollinariae Kapets et Khomyak in Kapets et al. 2018 (this paper)

Cl. Verrucarietea nigrescentis Wirth 1980

Ord. Verrucarietalia nigrescentis Klement 1950

All. Aspicilion calcareae Albertson ex Roux 1978

Aspicilietum contortae Kaiser ex Klement 1955

Cl. Ceratodonto purpurei-Polytrichetea piliferi Mohan 1978

Ord. Peltigeretalia Klement 1949

All. Cladonion arbusculae Klement 1949

Cladonietum mitis Krieger 1937 
Characteristics of the associations

\section{Ass. Aspicilio cinerei-Ramalinetum pollinariae \\ Kapets et Khomyak, ass. nova, hoc loco}

Holotypus hoc loco: Table 1, relevé № 6 (Zhytomyr Oblast, Korostyshiv Rayon, the northeast outskirts of Horodske village, the right bank of the Teteriv River, outcrops, $50^{\circ} 22^{\prime}$ 26.5” N, 29 10' 53.3" E, alt. 175 m a.s.1.; Sampled by N. Kapets on 8 August 2016).

Diagnostic species: Aspicilia cinerea, Ramalina pollinaria.

Constant species: Ramalina pollinaria, Candelariella vitellina.

Dominant species: Ramalina pollinaria, Aspicilia cinerea, Protoparmeliopsis muralis, Physcia dubia, Rhizocarpon eupetraeum.

The association of epilithic lichens is found in the Ukrainian Crystal Shield's outcrops (Fig. 2). This community occurs on inclined, almost vertical and perched surfaces mainly of the northern and northwest exposures. The average number of species per relevé is 7.7. The community characterised by a high total cryptogam layer cover consisted of $40-60 \%$, with a significant proportion of the substrate surface remaining bare. The cover of lichens ranged from 40 to $90 \%$. The bryophytes are not always present and their cover usually does not exceed $20 \%$. The minimum range of the association is $30 \mathrm{~cm}^{2}$. Rather acidophytic, mesophytic moderately photophytic, usually occurred in sun-exposed sites without extreme solar irradiation. The characteristic feature of communities of this association is presence of fruticose lichen Ramalina pollinaria in the species composition (cover up to $20-75 \%$ ). This association was described on mesophilous damp and shaded vertical or perched surfaces of outcrops.

\section{Ass. Aspicilietum cinereae Frey 1922}

Syn.: Aspicilia gibbosa-Ges. Mattick 1937, Lecanoretum sordidae Hilitzer 1936, Candelarilletum vitellinae Motyka 1925, Lecanora polytropa-Ges. Mattick 1937, Aspicilia cinerea-Ass. Hilitzer 1927.

Diagnostic species: Aspicilia cinerea, Circinaria caesiocinerea, Circinaria gibbosa, Lecanora rupicola.

Constant species: Acarospora fuscata, Aspicilia cinerea, Candelariella vitellina, Lecidea fuscoatra, Polysporina simplex, Protoparmeliopsis muralis.

Dominant species: Acarospora fuscata, Aspicilia cinerea, Candelariella vitellina, Lecidea fuscoatra, Polysporina simplex, Protoparmeliopsis muralis.

The boreal-Mediterranean, high-altitude association of epilithic lichens on well-illuminated, nutrient-rich, igneous rocks (Fig. 3). The average number of species per relevé is 9.3. The community characterised by a high total cryptogam layer cover consisted of $80-98 \%$ (Table 2). The cover of lichens ranged from 70 to $99 \%$. The bryophytes occurred rarely and had an insignificant cov- 


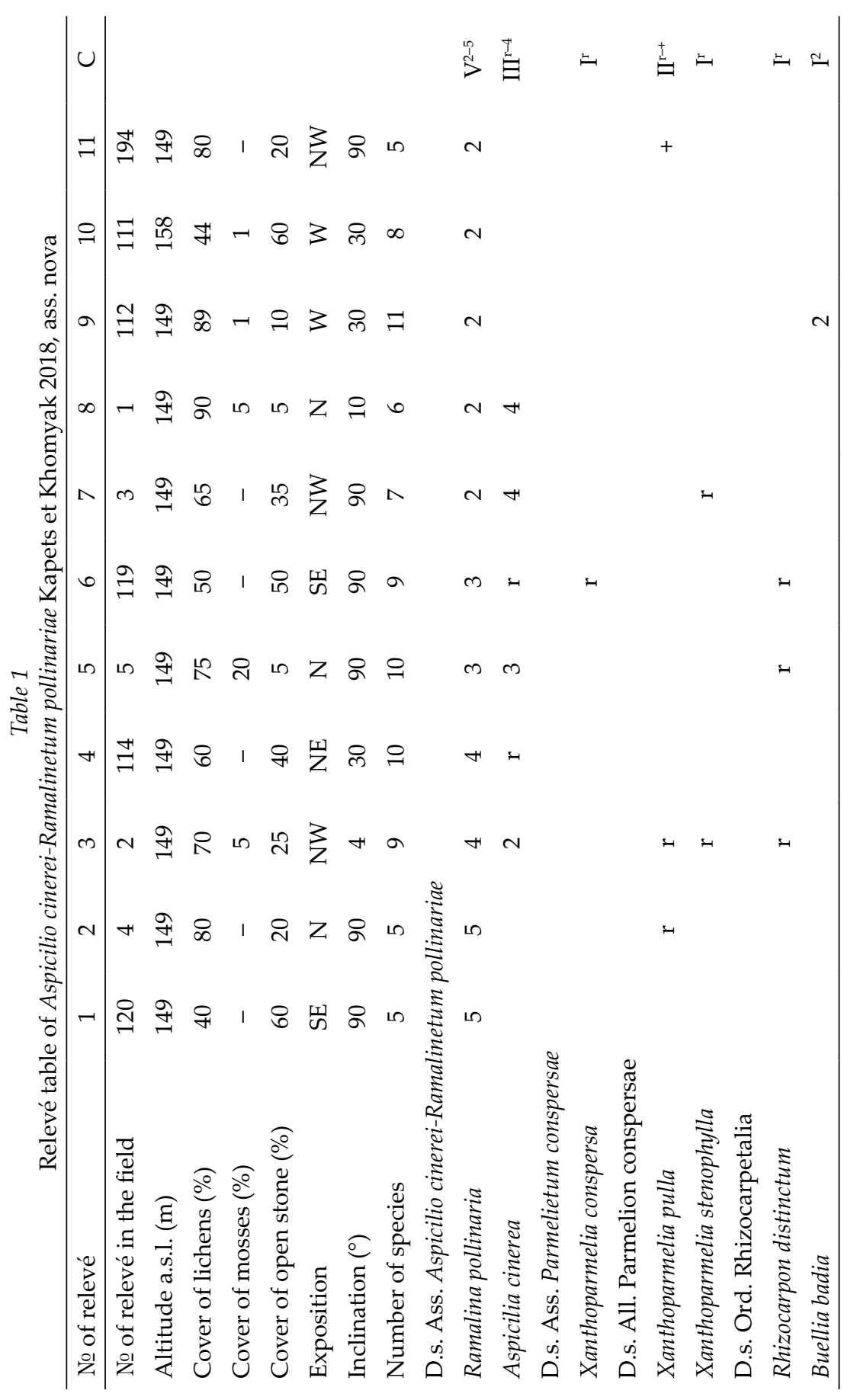




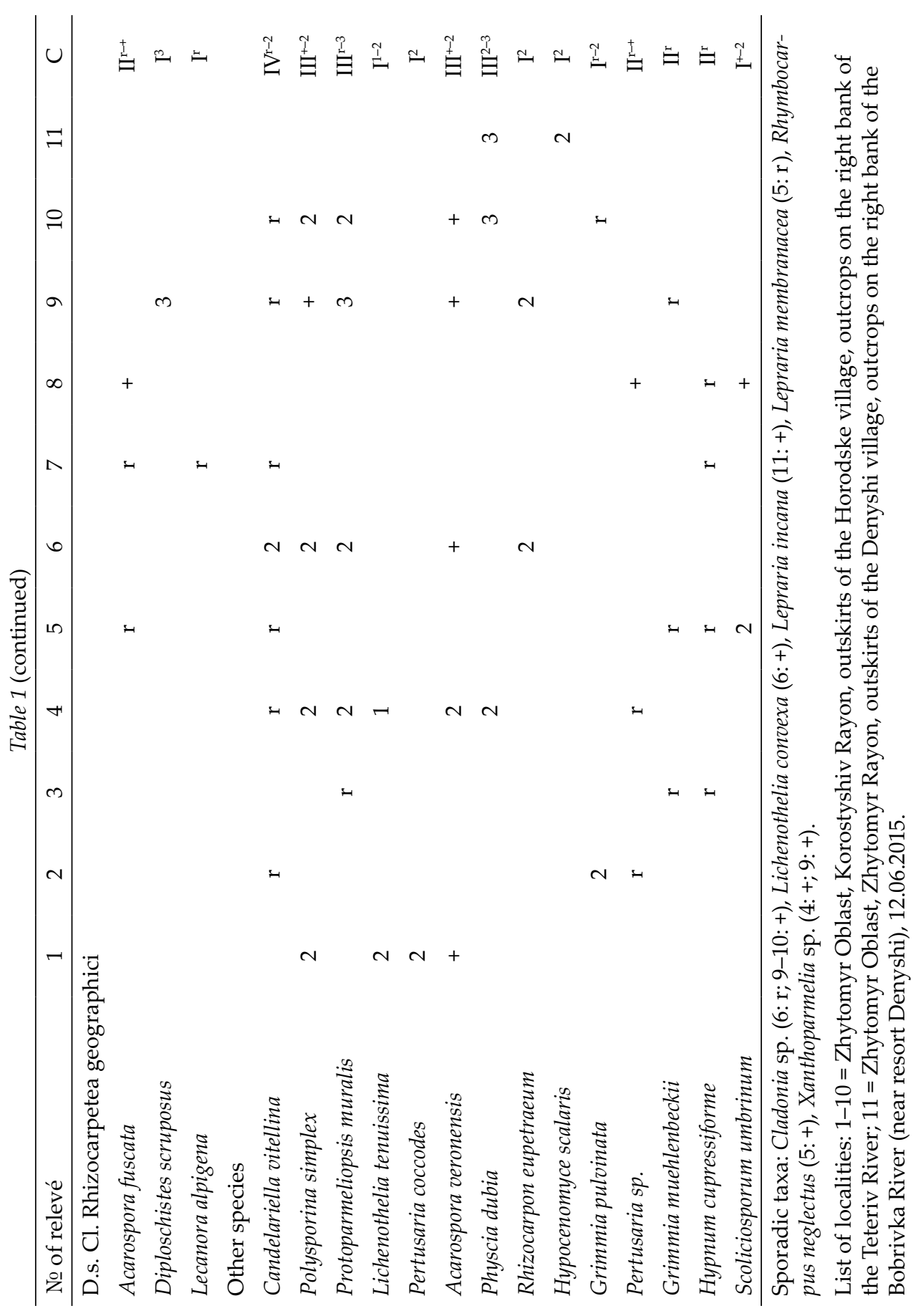




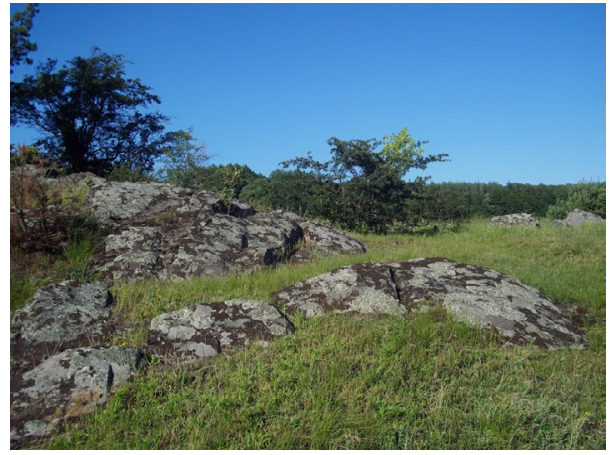

Fig. 1. Granite outcrops in the Teteriv River valley

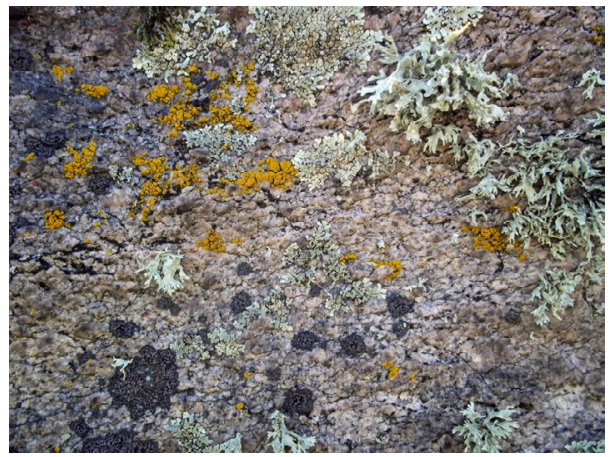

Fig. 2. The association Aspicilio cinerei-Ramalinetum pollinariae Kapets et Khomyak 2018

er. Rather subneutrophytic to subacidic, mesophytic, moderately photophytic, usually occurred in sun-exposed sites without extreme solar irradiation. The characteristic feature of communities of this association is predominance of crustose lichens, such as Acarospora fuscata, Aspicilia cinerea, Candelariella vitellina and Lecidea fuscoatra. The cover of foliose lichens on most of studied sites was very low, under $30 \%$. It is distributed on surfaces of different steepness and exposition. The association is fairly homogeneous, subassociations are not known.

\section{Ass. Parmelietum conspersae Hilitzer 1925}

Diagnostic species: Xanthoparmelia conspersa.

Constant species: Xanthoparmelia conspera, Xanthoparmelia pulla.

Dominant species: Xanthoparmelia conspera, Lecidea fuscoatra, Protoparmeliopsis muralis, Rhizocarpon distinctum.

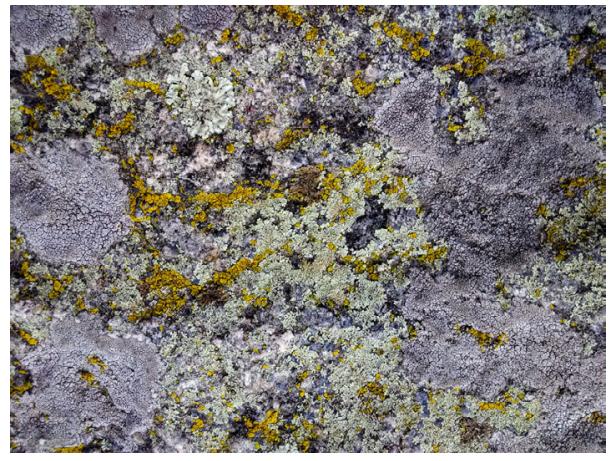

Fig. 3. The association Aspicilietum cinereae Frey 1922

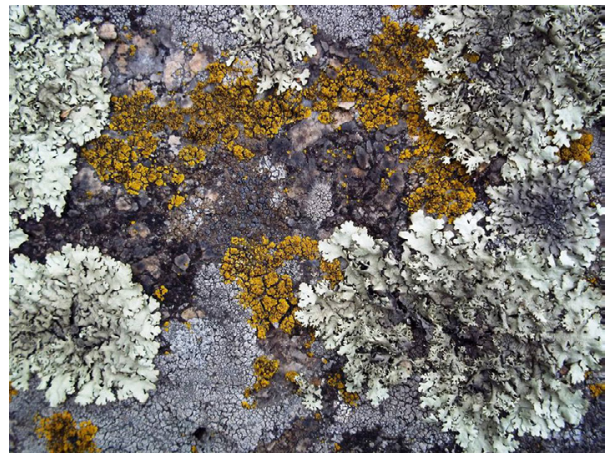

Fig. 4. The association Parmelietum somloensis Wirth 1995 
The boreal-Mediterranean, subcontinental association of epilithic lichens on well-illuminated, nutrient-rich, igneous rocks. The average number of species per relevé is 7.4. The association characterised by a high total cryptogam layer cover consisted of $70-98 \%$ (Table 3). The lichens cover ranged up 70 to $98 \%$. The cover of bryophytes does not exceed $2-30 \%$. The minimal area of the community is $30 \mathrm{~cm}^{2}$. Rather acidophytic, mesophytic, usually occurred in sun-exposed sites without extreme solar irradiation. It is distributed on surfaces of different steepness and exposition.

\section{Ass. Parmelietum somloensis V. Wirth 1995}

Syn.: Parmelietum molliusculae Gams 1927, Parmelietum stenophyllae Gams ex Klem. 1955, Parmelietum taracticae Klem. 1955.

Diagnostic species: Xanthoparmelia stenophylla.

Constant species: Xanthoparmelia stenophylla, Xanthoparmelia conspersa, Protoparmeliopsis muralis.

Dominant species: Sarcogyne simplex, Xanthoparmelia stenophylla.

The boreal-Mediterranean, subcontinental association of epilithic lichens on well-illuminated, nutrient-rich, igneous rocks (Fig. 4). The average number of species per relevé is 7.5. The total cryptogamic layer cover was high and consisted of 70-98\% (Table 4). The lichen cover constituted $80-95 \%$, the cover of bryophytes does not exceed $10 \%$. Subacidophytic to subneutrophytic, mostly mesophytic, usually occurred in sun-exposed sites without extreme solar irradiation. The community was common on partially shaded outcrops. The association is quite variable. Our research resulted in identifying subassociation Parmelietum somloensis var. Xanthoparmelia pulla. The subassociation is different due to availability of the foliose lichen Xanthoparmelia pulla. Communities of the association are distributed on surfaces of different steepness and exposition.

\section{Ass. Aspicilietum contortae Kaiser ex Klement 1955}

Diagnostic species: Aspicilia contorta.

Constant species: Aspicilia contorta, Candelariella vitellina, Protoparmeliopsis muralis, Sarcogyne simplex.

Dominant species: Aspicilia contorta, Bellemerea cupreoatra, Caloplaca atroflava, Candelariella vitellina, Endocarpon trachyticum, Protoparmeliopsis muralis, Sarcogyne simplex, Acarospora sp., Verrucaria nigrescens.

The subboreal, European-Mediterranean association of epilithic lichens on calcareous rocks. The average number of species per relevé is 8.2. The association characterised by a high total cryptogamic layer cover ranged from 65 to $90 \%$ (Table 5). Bryophytes are not always present, only three species hav- 


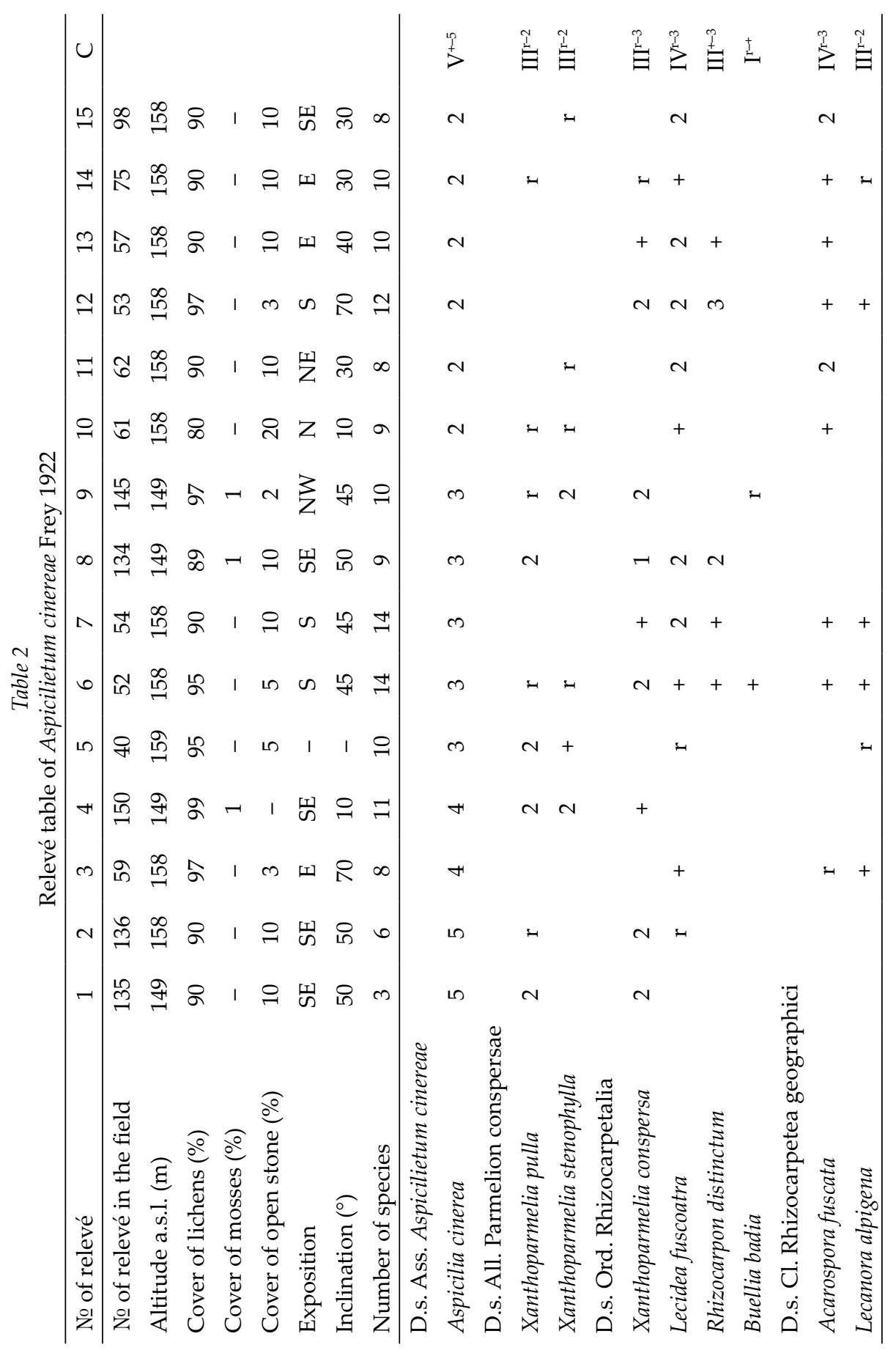




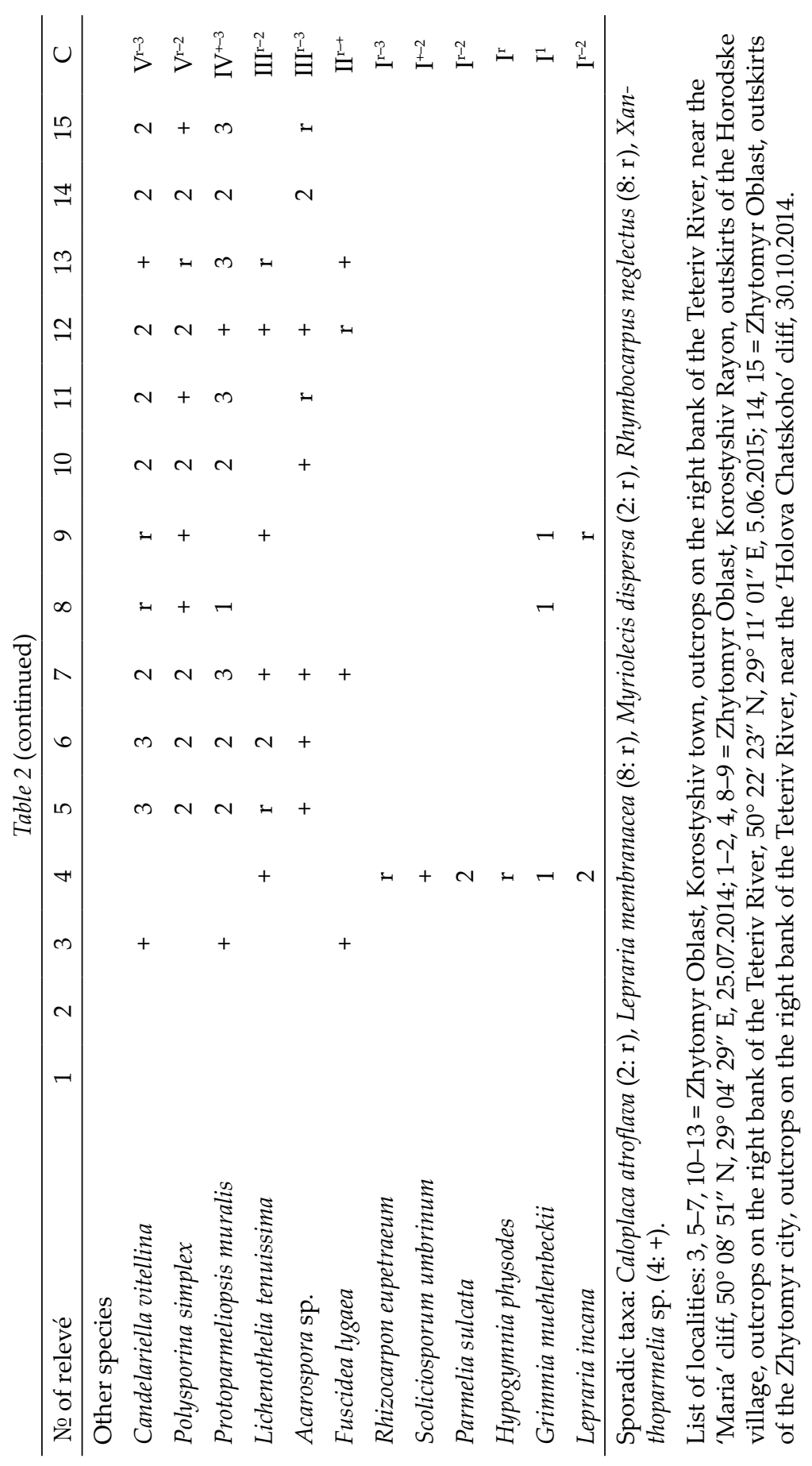




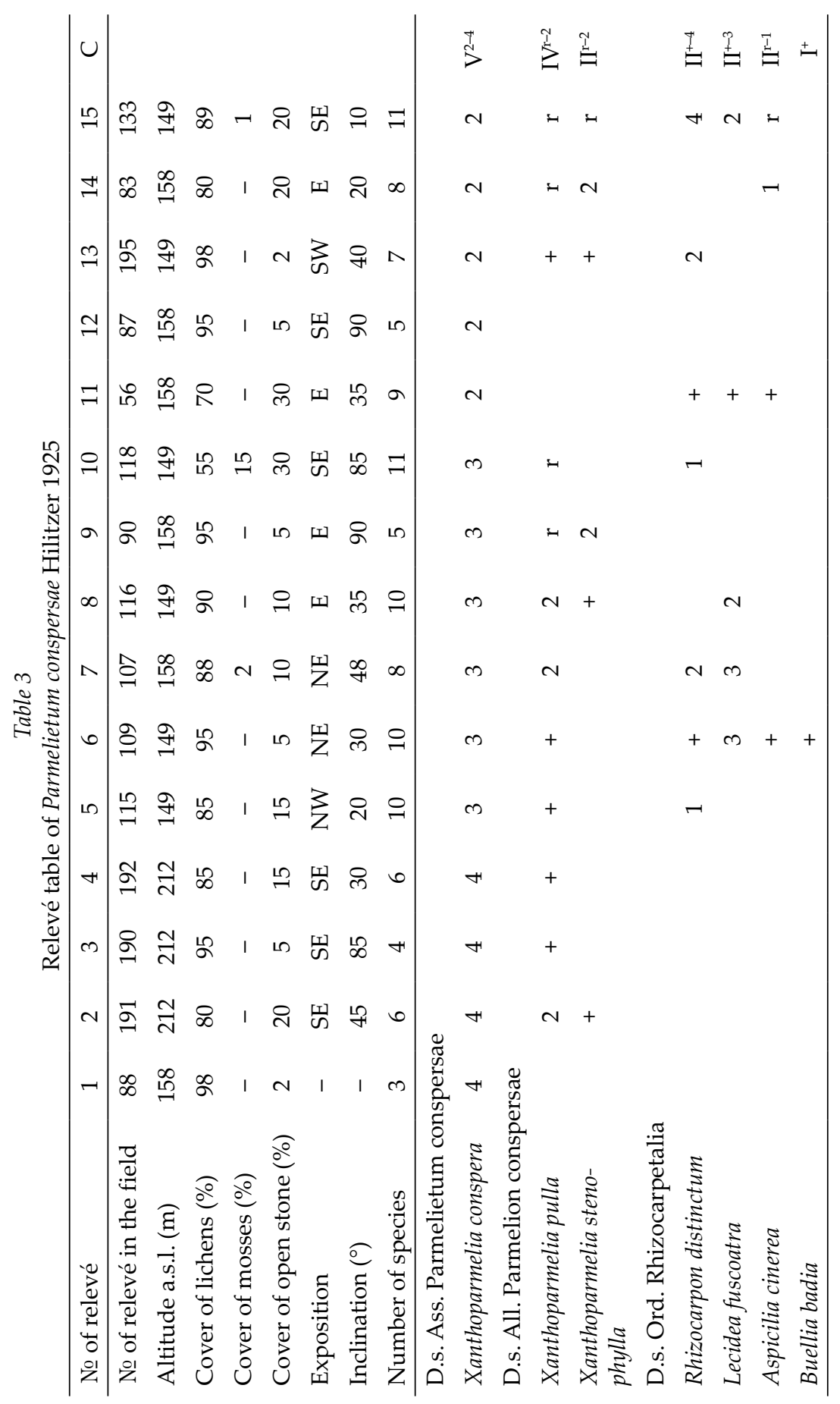




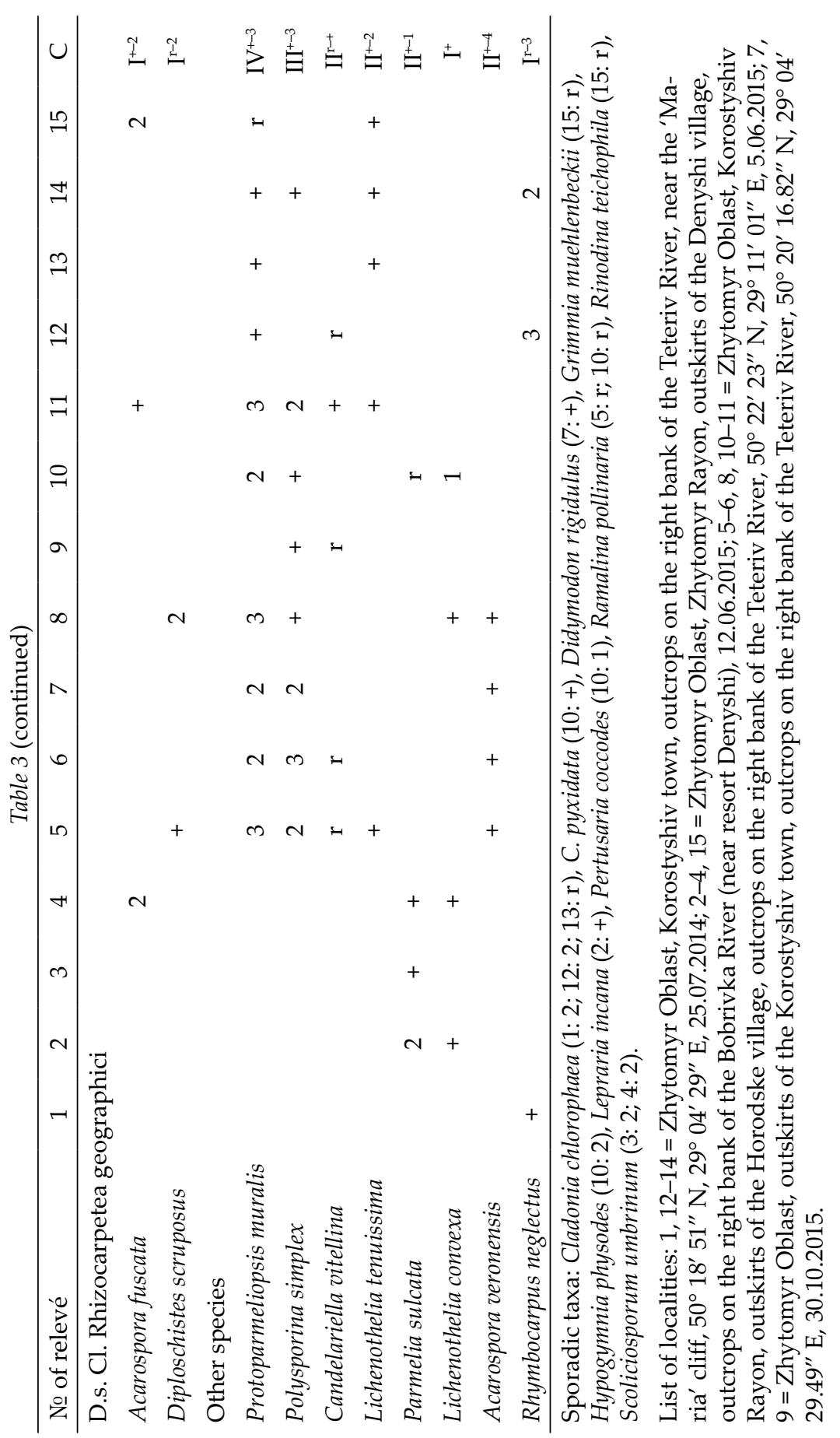




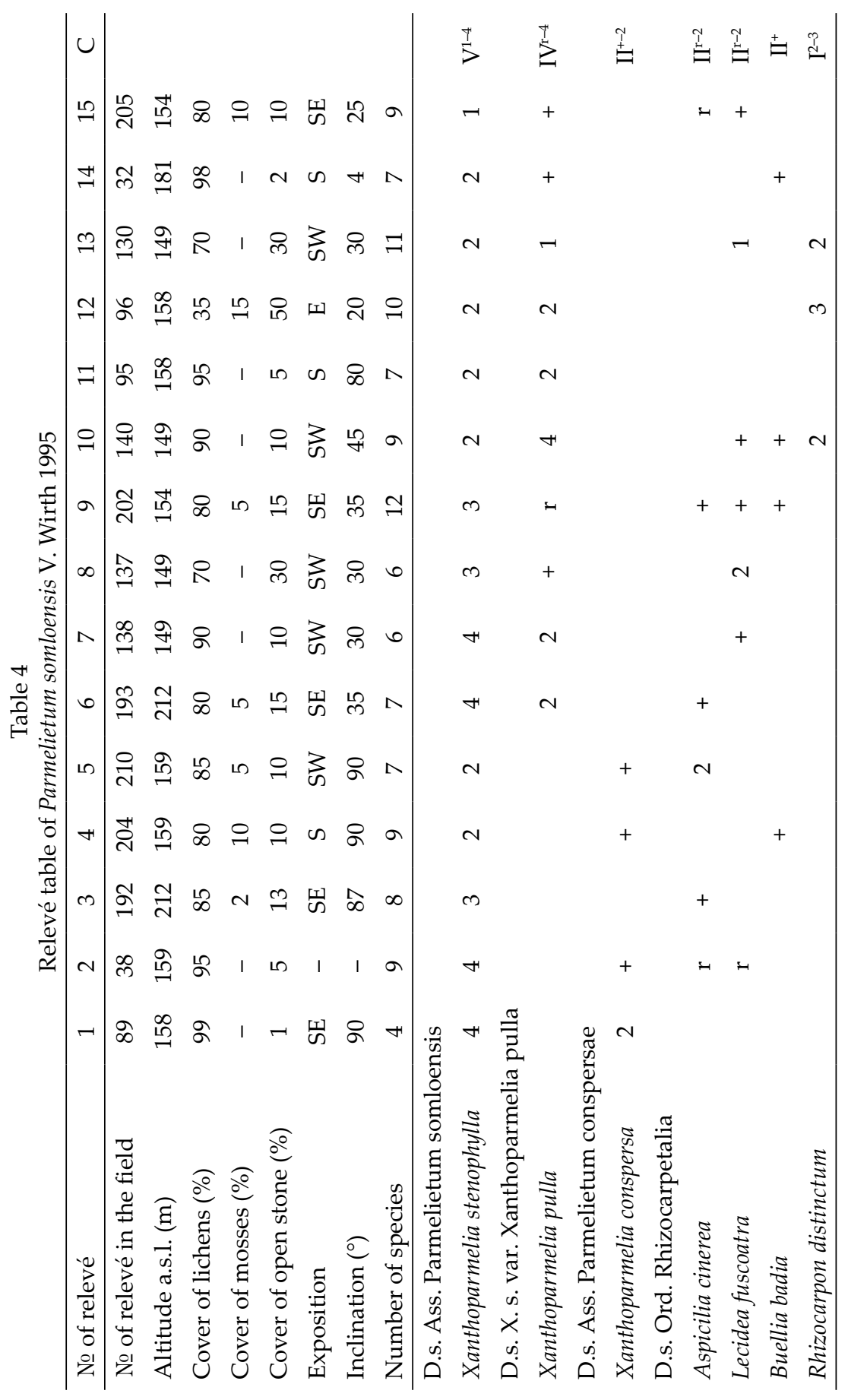




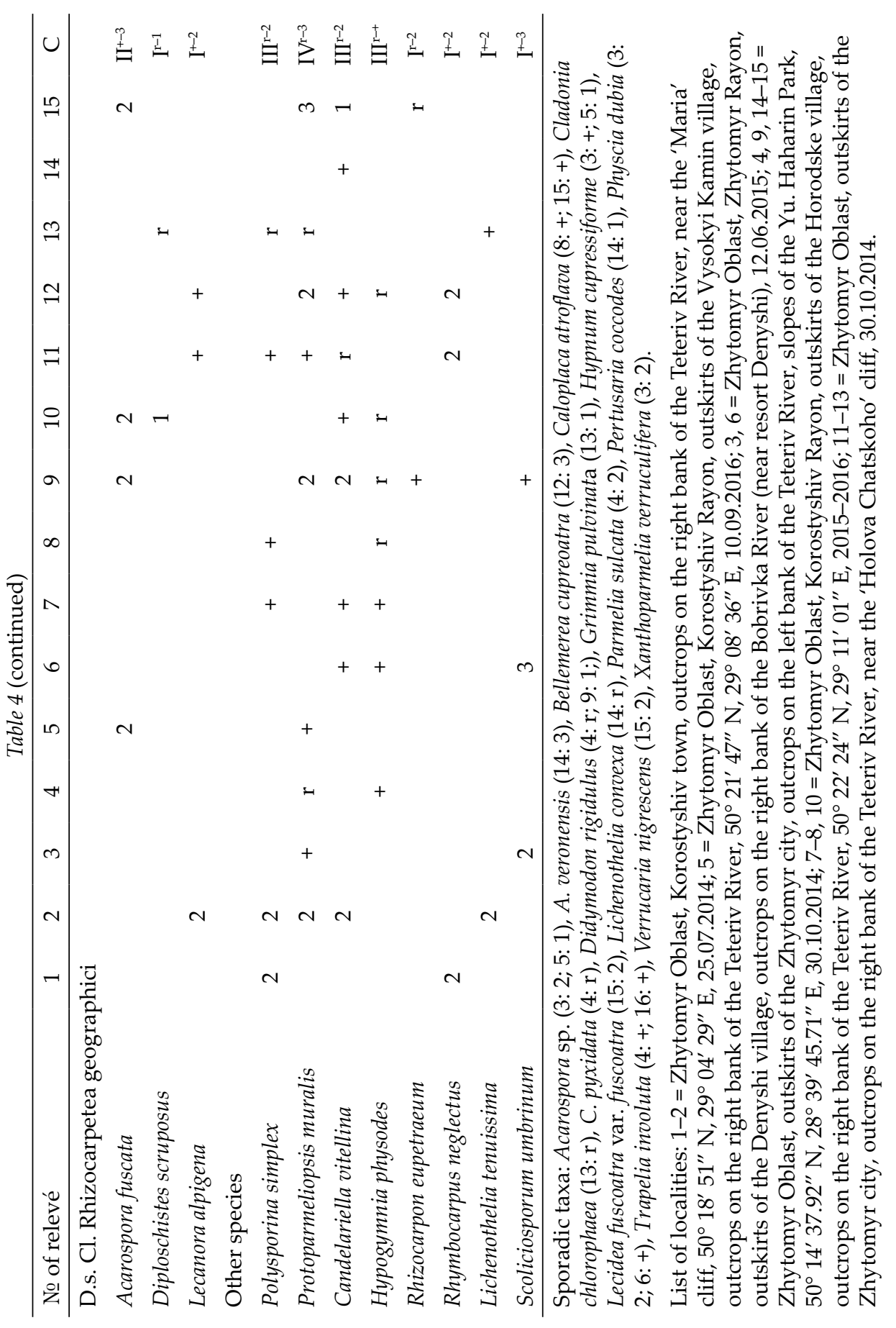




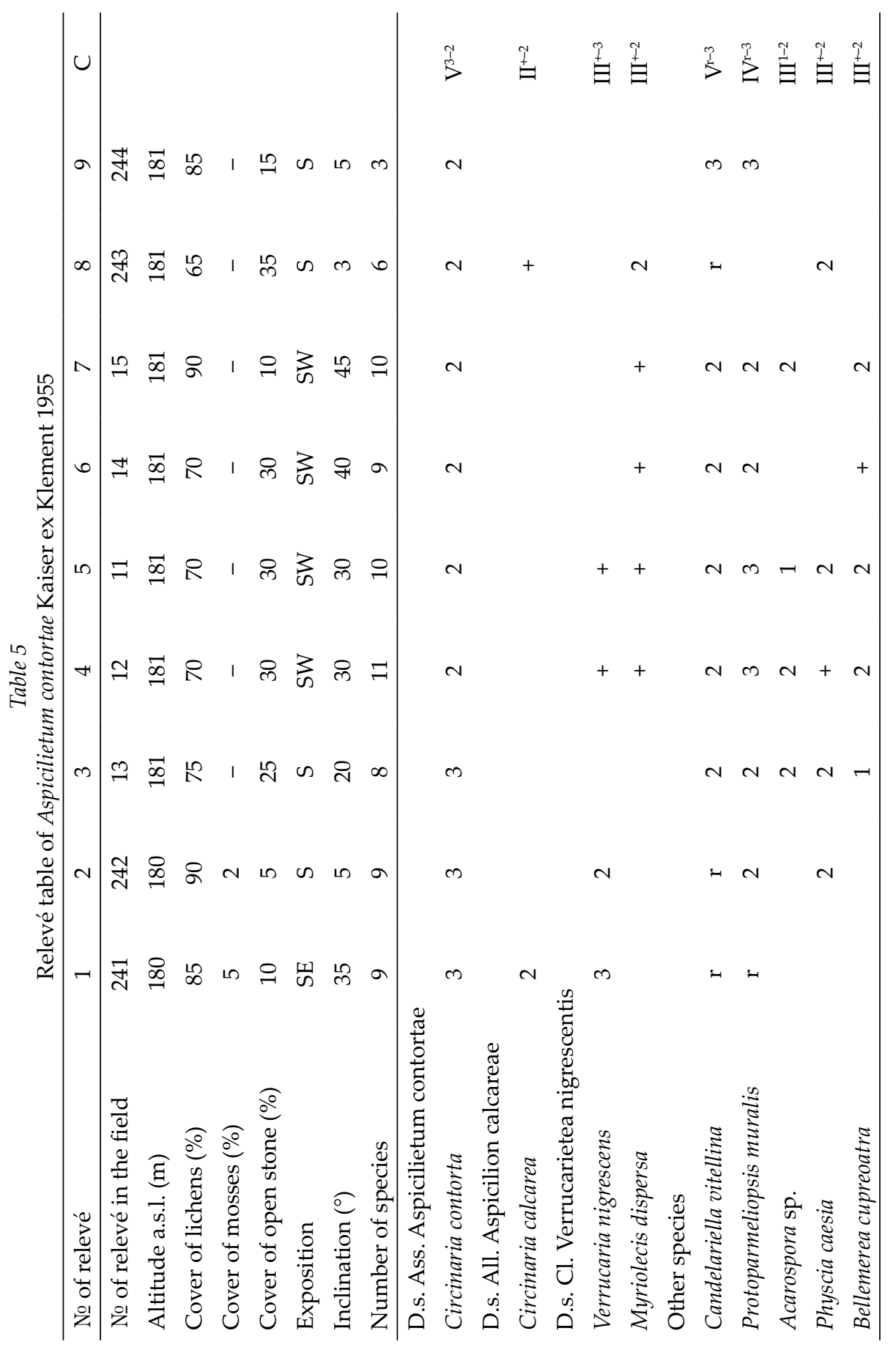




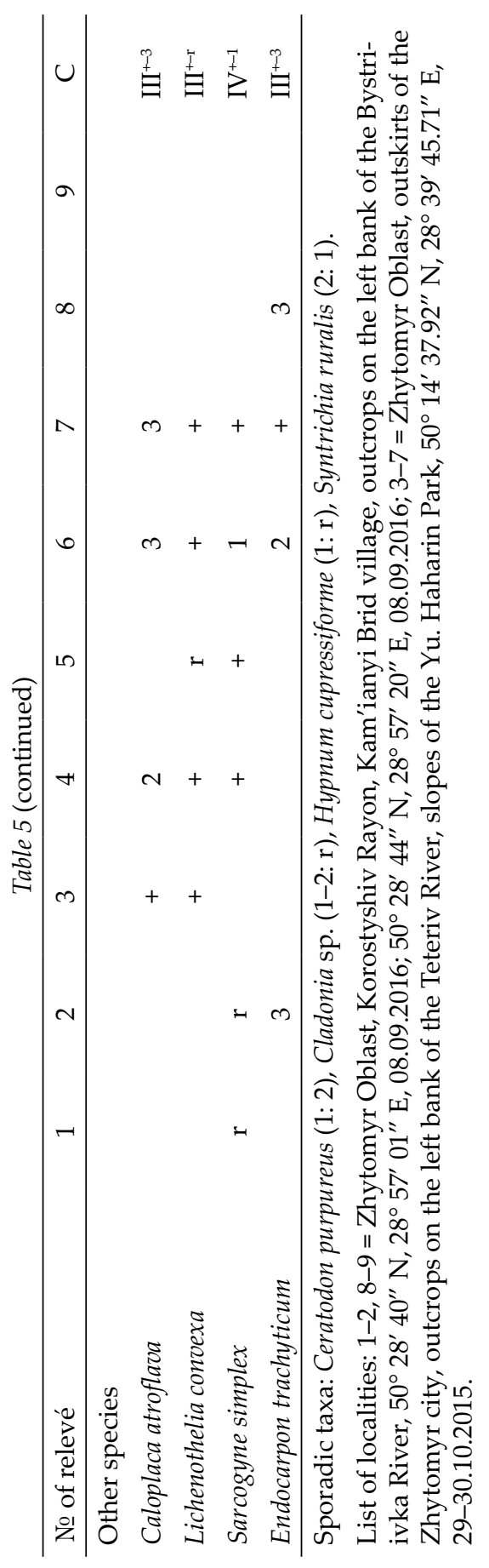

ing low coverage (not exceeding 5\%) were identified. The total cryptogamic cover constituted $65-90 \%$. The association includes mainly crustose lichens with grey, grey-black, black and brown slate. Rather subacidophytic to subneutrophytic, mesophytic to xerophytic avoiding extremely arid stands, occurred in sun-exposed sites without extreme solar radiation. Association was found on labradorite and granite outcrops and distributed on surfaces of different steepness and exposition.

\section{Ass. Cladonietum mitis Krieger 1937 \\ Diagnostic species: Cladonia mitis, C. portentosa.}

Constant species: Cladonia chlorophaea, C. furcata, C. portentosa, Peltigera malacea, Polytrichum piliferum.

Dominant species: Cladonia portentosa, C. furcata, Peltigera malacea, Polytrichum piliferum.

The boreal-Mediterranean, subcontinental, photophilous, acidophilous, mesophytic association of epigeic

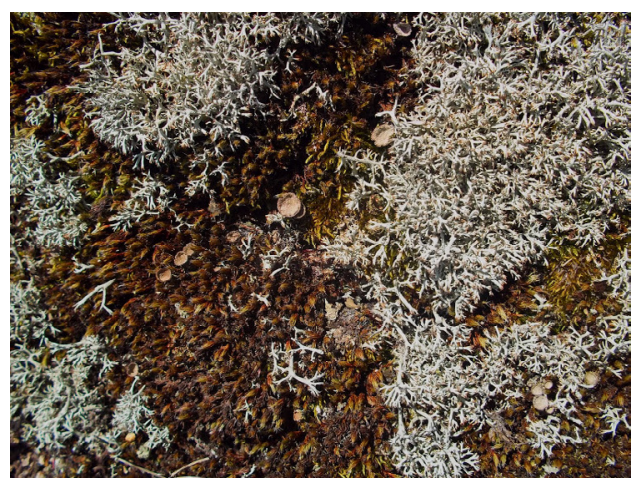

Fig. 5. The association Cladonietum mitis Krieger 1937 


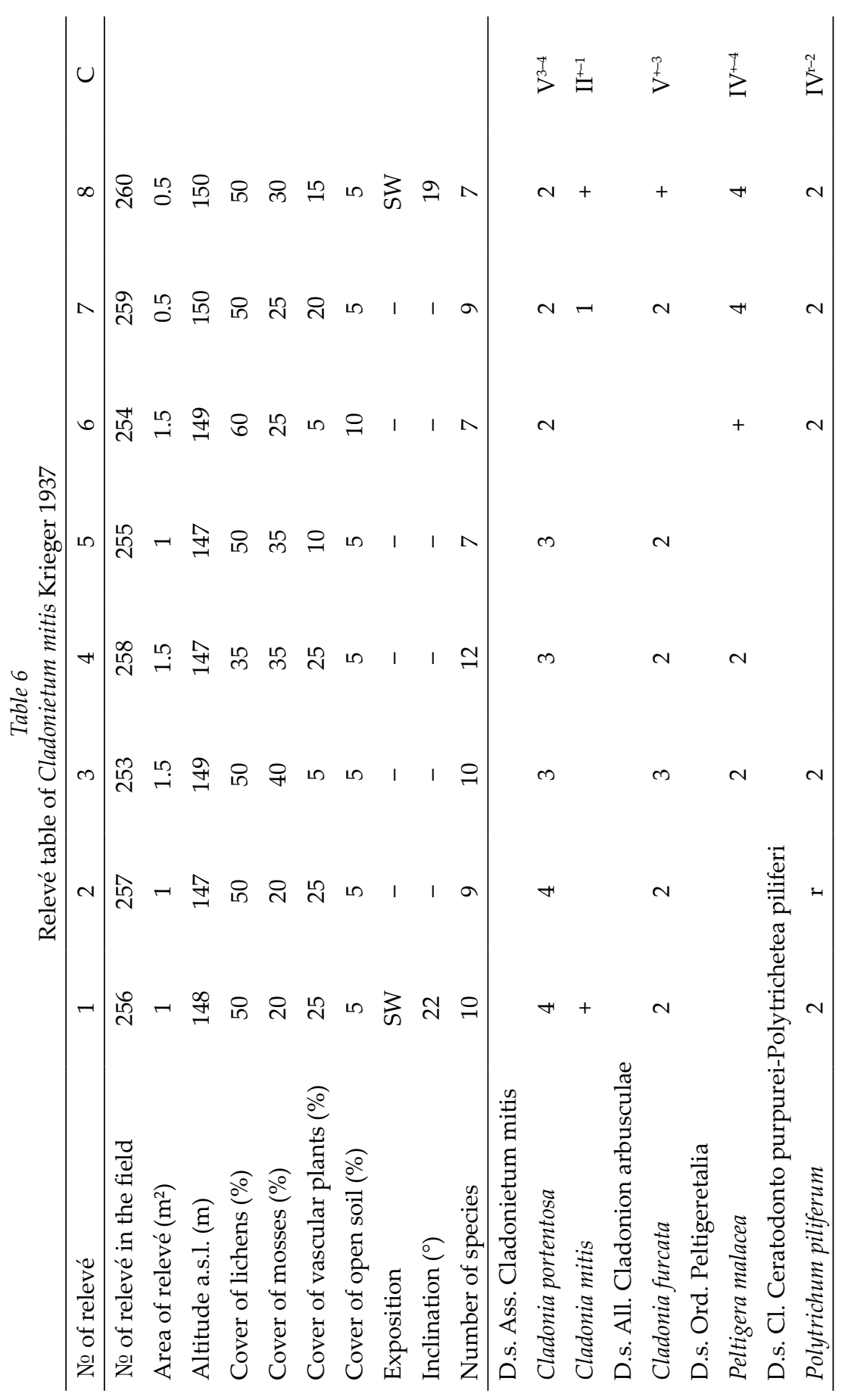




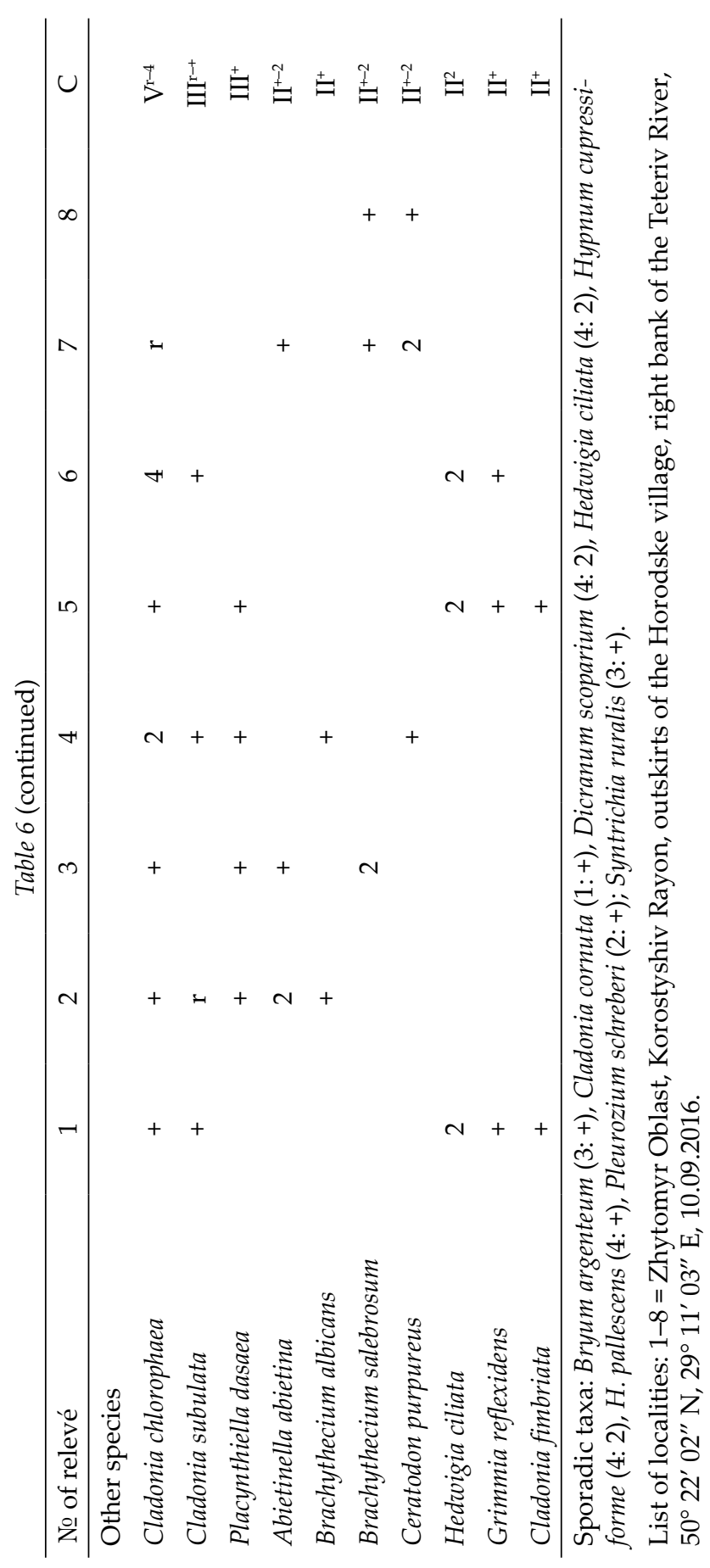




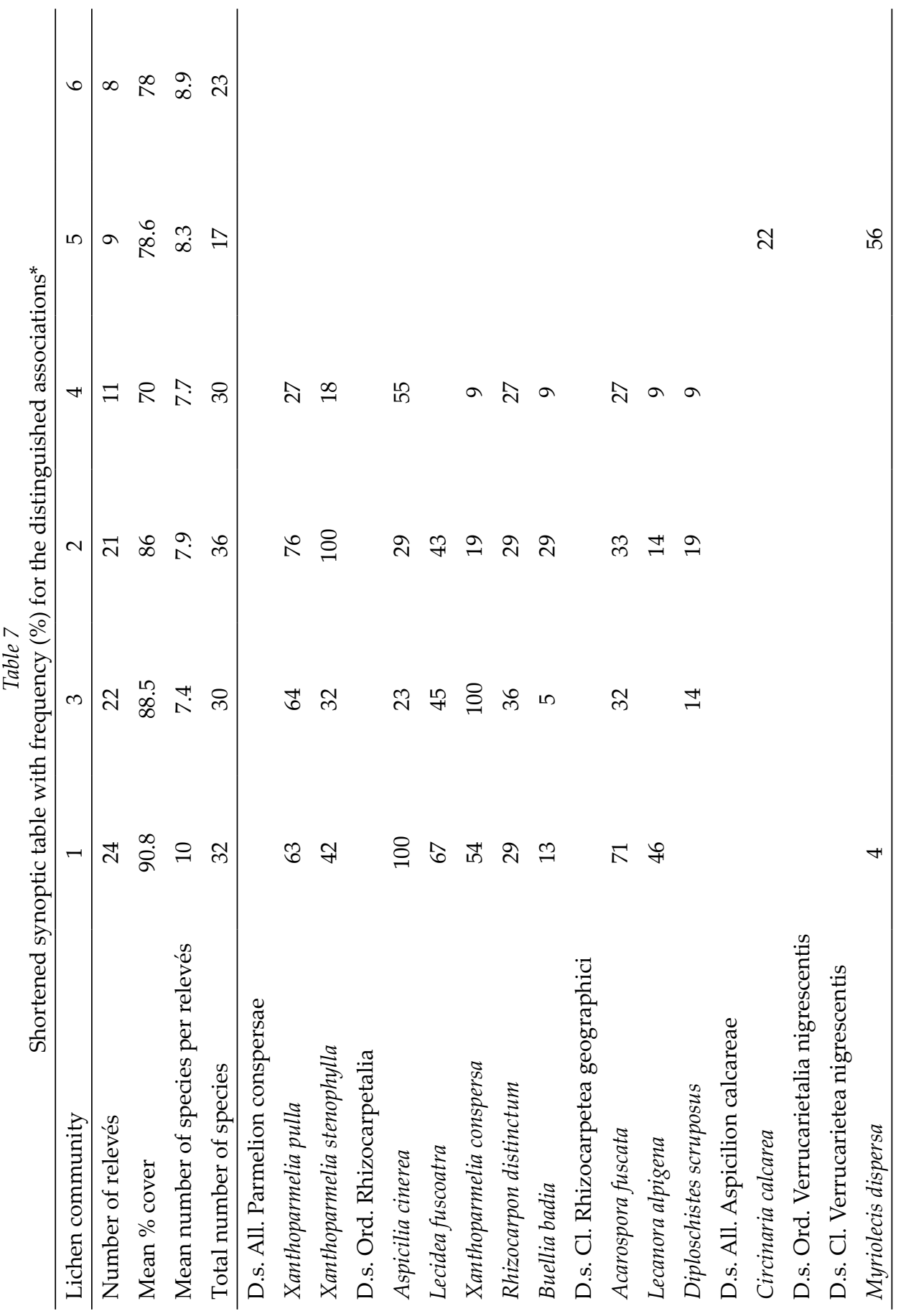




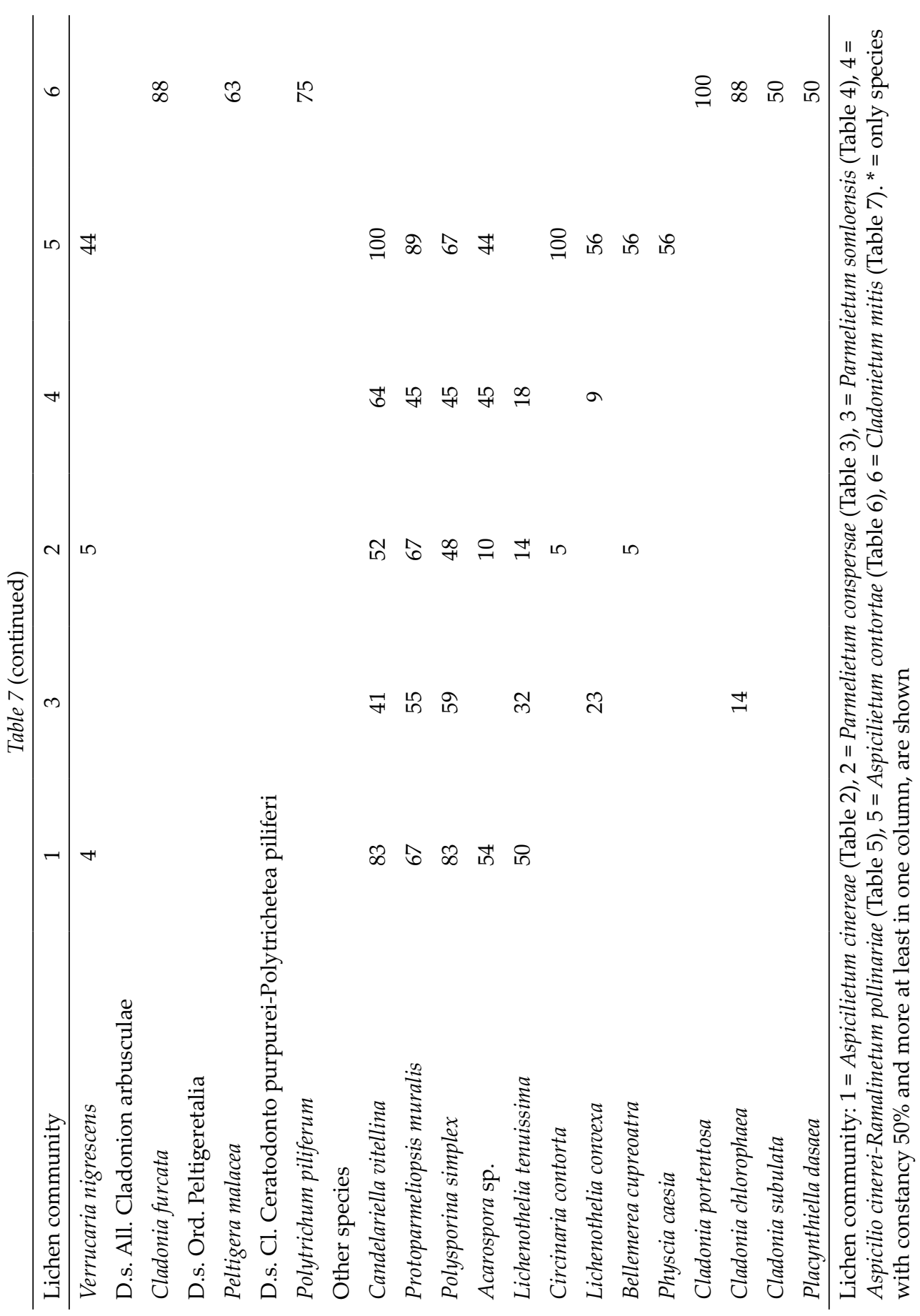


lichens on nutrient-poor soils (Fig. 5). The average number of species per relevé is 8.8 . The association characterised by a high total cryptogamic layer cover consisted of $70-90 \%$ (Table 6). The lichen cover is up to $35-60 \%$, the cover of bryophytes varied from 20 to $40 \%$. The vascular plant layer was rare and sparse (up to $25 \%$ ). The minimal area of its communities is $0.5 \mathrm{~m}^{2}$. The species composition of the association has a well-defined biological component. Rather subacidophytic to subneutrophytic, mesophytic, occurred in sun-exposed sites without extreme solar radiation. The association is quite variable, the cover of lichens and bryophytes varies depending on natural conditions. It is usually found on even or occasionally on slightly sloping surfaces of different exposures. In the study area, it is often found on almost horizontal sections of granite outflows underlying thin layer of accumulated soil.

\section{DISCUSSION}

The epilithic lichen communities of the Teteriv River basin are common on siliceous outcrops of the Ukrainian Crystalline Shield located in the forest zone of Ukraine. Only one epigeic association Cladonietum mitis was described on siliceous screes near outcrops along the river bank. The distinctive features of all studied associations are poor species composition including 3-14 of lichen and moss species per relevés (the mean species per relevé is 8.4) and high total cryptogamic cover (up to $98 \%$ ). We believe that it is mainly determined by the natural conditions of the territory, particularly, by humidity level and the chemical composition of substrate (in most cases, the species composition of lichens on siliceous substrate is poorer than on carbonates). The mean environmental values of all associations are fairly homogeneous and indicate that the studied communities rather acidophytic to neutrophytic, photophytic, mesophytic to slightly xerophytic. More detailed analysis of ecological characteristics of lichen communities requires the development of ecological indicator values adapted for Ukraine.

Crustose lichens prevail in floristical compositions of the epilithic lichen associations from the classes Rhizocarpetea geographici and Verrucarietea nigrescentis, with higher coverage; where the foliose and fruticose species are much less distributed and their coverage is less, as well. Lichens with leprose crustose thallus are very rare and usually occur in some more shaded and wet sites. The fruticose lichen Ramalina pollinaria occurs sporadically in the epilithic communities from class Rhizocarpetea geographici and this species is diagnostic to the new association Aspicilio cinerei-Ramalinetum pollinariae. Species with Cladonia-type thallus are rare in all epilithic associations and dominate in the epigeic association Cladonietum mitis.

Lichens, such as Acarospora fuscata, Candelariella vitellina, Lecidea fuscoatra, Polysporina simplex, Protoparmeliopsis muralis are the most frequent species for 
all epilithic associations. Some of them are diagnostic to syntaxa of different rank (Table 7). Candelariella vitellina, Polysporina simplex and Protoparmeliopsis muralis occur in more than $60 \%$ of all relevés. According to our observations, the foliose and fruticose species are almost completely absent and some crustose species (Candelariella vitellina, Lecidea fuscoatra, Polysporina simplex, Protoparmeliopsis muralis) have very high coverage on the rock surfaces actively exposed to anthropogenic influences (trampling, breeding of honeycombs, etc.).

\section{CONCLUSIONS}

This study is the first attempt to explore the lichen communities of the Teteriv River basin. Five epilithic lichen associations, one subassociation of two alliances and two orders of the classes Rhizocarpetea geographici and Verrucarietea nigrescentis, and one epigeic lichen association, one alliance and one order of the class Ceratodonto purpurei-Polytrichetea piliferi have been described. The associations Aspicilietum contortae, Cladonietum mitis, Parmelietum conspersae, Parmelietum somloensis and the alliance Aspicilion calcareae were found to be new for Ukraine, as well as the new association Aspicilio cinerei-Ramalinetum pollinariae is described in this paper.

The results of our study covering lichen communities of Teteriv River basin is merely a small contribution to developing syntaxonomy of Ukraine's cryptogamic vegetation. We hope that this field will be developed rapidly in Ukraine, and much more information will appear soon covering this subject.

Acknowledgements - The authors are grateful to Prof. S. Y. Kondratyuk (Kiev, Ukraine) for his advice and support during this research and useful remarks to the manuscript; and Dr L. Lőkös (Budapest, Hungary) for his valuable and detailed comments, which allowed us to improve the manuscript.

\section{REFERENCES}

Boiko, M. F. (2008): A checklist of the bryobionta of Ukraine. - Aylant, Kherson, 264 pp. [in Ukrainian]

Boiko, M. F. (2014): The second checklist of bryobionta of Ukraine. - Chornomors'k. Bot. Z. 10(4): 426-487. https://doi.org/10.14255/2308-9628/14.104/2

Braun-Blanquet J. (1964): Pflanzensoziologie: Grundzuge der Vegetationskunde. 3 Aufl. Springer Verlag, Wien, New York, 865 pp.

Bültman, H. and Daniëls, A. (2009): Lichens and vegetation - a case study of Thamnolietum vermicularis. - Bibl. Lichenol. 100: 31-47.

CABI (2016): The Index Fungorum. - http://www.indexfungorum.org. (accessed 5 January 2018) 
Chytrý, M., Tichý, L., Holt, J. and Botta-Dukát, Z. (2002): Determination of diagnostic species with statistical fidelity measures. - J. Veg. Sci. 13: 79-90. https://doi.org/10.1658 /1100-9233(2002)013[0079:dodsws]2.0.co;2

Didukh, Y. P., Fitsailo, T. V., Korotchenko, I. A., Iakushenko, D. M. and Pashkevych, N. A. (2011): Biotopes of forest and forest-steppe zones of Ukraine. - Ltd. MAKROS, Kyiv, 288 pp. [in Ukrainian]

Gapon, S. V. (2013): Bryocommunities of natural vegetation types of the Ukrainian Forest-Steppe. - Chornomors'k. Bot. Z. 9(2): 257-264. https://doi.org/10.14255/2308-9628 /13.92/10 [in Ukrainian]

Hennekens S. M. (2009): TURBOVEG for Windows. Version 2. - Inst. voor Bos en Natuur, Wageningen, $84 \mathrm{pp}$.

Hill, M. O. (1979): TWINSPAN - Fortran program for arranging multivariate data in an ordered two-way table by classification of the individuals and attributes. - Cornell University, Ithaca, New York, 48 pp.

Khodosovtsev, O. Ye. (2015): Endocarpo-Xanthocarpion tominii all. nov. and Caloplacetum albolutescentis ass. nov., a new syntaxa of lichen communities from loess outcrops in southern Ukraine. - Chornomors'k. Bot. Z. 11(3): 317-326. https://doi.org/10 $.14255 / 2308-9628 / 15.113 / 4$ [in Ukrainian]

Khodosovtsev, O. Ye., Nadyeina, O. V. and Khodosovtseva, Yu. A. (2014): Terricolous lichen communities of Plain Crimea (Ukraine). - Chornomors'k. Bot. Z. 10(2): 202-223. https://doi.org/10.14255/2308-9628/14.102/5 [in Ukrainian]

Khodosovtsev, O. Ye., Boiko, M. F., Nadyeina, O. V. and Khodosovtseva, Yu. A. (2011) Lichen and bryophyte associations on the lower Dnieper sand dunes: syntaxonomy and weathering indication. - Chornomors'k. Bot. Z. 7(1): 44-46. https://doi.org/10 .14255/2308-9628/11.71/5 [in Ukrainian]

Klement, O. (1955): Prodromus der mitteleuropäischen Flechtengesellschaften. - Feddes Repert., Beih. 135: 1-194.

Kondratyuk, S. Ya. and Martynenko, V. G. (2006): Lichen indication. - Kod, Kiev, Kirovograd, 260 pp. [in Ukrainian]

Marinich, A. M. (1963): The geomorphology of South Polessye. - Publishing house of Kyiv State University, Kiev, 252 pp. [in Russian]

Marinich, A. M., Pashchenko, V. M. and Shyshchenko, P. H. (1985): The nature of the Ukrainian SSR. Landscapes and physical-geographical regionalization. - Naukova Dumka, Kiev, 224 pp. [in Russian]

Mirkin, B. M. and Rozenberg, G. S. (1983): Modern phytocenology defining dictionary. - Nauka, Moscow, 133 pp. [in Russian]

Mucina, L., Bültmann, H., Dierssen, K., Theurillat, J.-P., Raus, T., Čarni, A., Šumberová, K., Willner, W., Dengler, J., Gavilán García, R., Chytrý, M., Hájek, M., Di Pietro, R., Iakushenko, D., Pallas, J., Daniëls, F. J. A., Bergmeier, E., Santos Guerra, A., Ermakov, N., Valachovič, M., Schaminée, J. H. J., Lysenko, T., Didukh, Y. P., Pignatti, S., Rodwell, J. S., Capelo, J., Weber, H. E., Solomeshch, A., Dimopoulos, P., Aguiar, C., Hennekens, S. M. and Tichý, L. (2016): Vegetation of Europe: hierarchical floristic classification system of vascular plant, bryophyte, lichen, and algal communities. Appl. Veg. Sci. 19(1): 3-264. https://doi.org/10.1111/avsc.12257

Nimis, P. L. and Martellos, S. (2008): ITALIC - The information system on Italian lichens. Version 4.0. - University of Trieste, Dept. of Biology. http://dbiodbs.units.it

Orlov, O. O. and Yakushenko, D. M. (2005): Plant cover of projected Korostyshiv Nature National Park. - Fitosotsiotsentr, Kyiv, 180 pp. [in Ukrainian] 
Oxner, A. N. (1927): To study of the lichen flora of rocky outcrops of Ukraine. - Bull. Kyiv Bot. Garden 5(6): 23-82.

Paus, S. M. (1997): Die Erdflechtenvegetation Nordwestdeutschlands und einiger Randgebiete. - Bibl. Lichenol. 66: 1-207.

Redchenko, A. A. (2004): The lichens of coastal line of the Crimea. - Manuscript, Thesis for a Candidate Degree, M. G. Kholodny Institute of Botany of the National Academy of Sciences of Ukraine, Kiev, 22 pp. [in Ukrainian]

Tichý, L. (2002): JUICE, software for vegetation classification. - J. Veg. Sci. 13: 451-453. https://doi.org/10.1111/j.1654-1103.2002.tb02069.x

Weber, H. E., Moravec, J. and Theurillat, J.-P. (2000): International code of the phytosociological nomenclature. 3rd edition. - J. Veg. Sci. 11: 739-768. https://doi.org/10.2307 13236580

Wirth, V. (2010): Ökologische Zeigerwerte von Flechten - erweiterte und aktualisierte Fassung. - Herzogia 23: 229-248. https://doi.org/10.13158/heia.23.2.2010.229 